\title{
Total Factor Productivity in Food Industries of Iran
}

\author{
Ahmad Afrooz (Correspondent Author) \\ Economics Department of Payam Noor university, Iran \\ E-mail:afz1000@yahoo.com
}

\author{
Khalid B Abdul Rahim, Zaleha Bt Mohd Noor \& Lee Chin \\ Faculty Of Economics And Management, University Putra Malaysia
}

\begin{abstract}
Considering to Importance of Food Industries (Priority of the Non-oil Exports in Foreign Trade, respond to Nutrition of population and Prevention of Wastage) This paper examines the levels of labor, total productivity and technical changes in food industries and compare with total industries of Iran over the period of 1971-2006. The results show that labor productivity and total factor productivity in food industries were lower than the average total industries over the period. Also, the estimation of technical changes has shown that the measure of technical change in food industries was 0.09 percent while for total industries was 0.16 percent over the period.
\end{abstract}

Keywords: Labor Productivity, Total Factor Productivity (TFP), Technical Changes

\section{Introduction}

The term productivity has been a key concept for national development strategy due to its impact on economic and social development. Today, the concept is not only known by economists and managers, but has all been involved in economic activity. Productivity is a notion that has profound importance in our lives. It can have major effects at the national, industrial and individual levels. At the national level, productive growth accounts for large proportions of growth in the nation's gross national product (GNP) and can help reduce inflation (Kendrick, 1984). At the firm and industry level, an increase in productivity can create competition that can lead to industry and firm growth (Pritchard, 1992). At the individual level, productivity can lead to improvements in the quality of life, increased leisure time and advancement within an organization (Kendrick, 1984; Pritchard, 1992). McGinn (2002) reflected on the impact productivity can have on a person's standard of living. Considering the importance of food industries of Iran, this paper examines productivity in food industries as being compared to total industry of Iran.

\subsection{Food Industry in Iran}

Food industry is recognized as a 'sunrise industry' in Iran, with huge potential for the enlistment of the agricultural economy, creation of large scale processed food, manufacturing, food chain facilities and the generation of employment and export earnings. As a result, this industry is one of the largest industries in Iran. Based on the recent reports (2006) by the Statistical Centre of Iran (SCI), the sector is ranked first in terms of employment (18 percent). Moreover, in terms of value-added, it is ranked third (16 percent).

Furthermore, the development of these industries would increase the demand for agricultural products in food processing and reduce the level of waste. The importance equally lies in identifying the strength and the weakness of the food industry in presenting scientific solutions to researchers. It will also assist economic policymakers to reach their program goals quickly. The brief importance of food industries is due to the three important factors; 1) Priority of the Non-oil Exports in Foreign Trade. 2) Respond to Nutrition of population. 3) Prevention of Wastage.

Now the main question is whether all the capacity of this industry has been used. In other words, how is the situation of total productivity in food industry; or what is the state of productivity growth of the food industry in the past 30 years as compared to the present?

\section{Literature review}

The word "productivity" appeared for the first time in an article by Quesnay (Note 1) in 1766. More than a century later in 1883, Littre defined productivity as the "faculty to produce" and this definition continued to appear in the Larouss dictionary.

In business or industrial context, it is the ratio of output production in relation to input efforts. While there is no disagreement with this notion, a look at productivity literatures and its various applications reveals that there is neither a unique purpose for, nor a single measure of productivity(OECD, 2001).

The economic theory of productivity measurement goes back to the work of Jan Tinbergen (1942;) and independently, to Robert Solow(1957) . These studies formulated productivity measures in a production function context and linked them to the analysis of economic growth:

$\mathrm{Y}(\mathrm{t})=(\mathrm{t}) \cdot \mathrm{F}[\mathrm{K}(\mathrm{t}), \mathrm{L}(\mathrm{t})]$

Where $\mathrm{Y}(\mathrm{t})$ stands for aggregate production (or aggregate income), $\mathrm{K}(\mathrm{t})$ is the stock of physical capital used in production, $\mathrm{L}(\mathrm{t})$ is the amount of labor inputs, and $\mathrm{A}(\mathrm{t})$ is the total factor productivity. 
International organizations of productivity (APO \& OECD) (Note 2) have attempted to present a practical guide for the measurement of productivity. Their attempt has been used to compare economies in terms of productivity. In recent years, there has been an increasing interest in the examination of productivity from different parts of the economy such as industry, agriculture, and services. Numerous studies have attempted to explain productivity in the economic sector, for example, productivity growth in Swedish manufacturing (Carlsson, 1981), the impact of regional investment incentives on employment and productivity in Canada (Daly, Gorman, Lenjosek, MacNevin, \& Phiriyapreunt, 1993), productivity and imperfect competition in Italian firms (Contini, Revelli, \& Cuneo, 1992), explaining total factor productivity differentials in urban manufacturing of U.S (Mullen \& Williams, 1990).

Total factor productivity growth in manufacturing has been examined by applied parametric and non-parametric approaches. In most of the studies have used non-parametric approach, wherein total factor productivity growth has decomposed into efficiency change and technological change. Efficiency change measures "catching-up" to the isoquant while technological change measures shifts in the isoquant. For example,see Weber and Domazlicky (1999) ;Nemoto and Goto (2005); Yu(2007); (Maniadakis and Thanassoulis (2004) and Radam (2007).

Several researchers used econometric approaches to estimate the level of TFP and growth rate of TFP in manufacturing. In this approach, the growth rate of TFP is measured as the residual growth in value added in manufacturing, after accounting for the contribution of input growth to value added. Lach (1995), Windle and Dresner (1992), Rushdi (2000), Eslava et al (2004), Lam and Lam (2005)and Mollick and Cabral (2009). In these researches, Translog production function and Cobb-Douglas production function form have been applied to estimate TFP growth and estimate the share of production inputs that utilized in index method.

In recent years, several attempts have been made to investigate productivity in different sectors of Iran economics. Most studies in productivity have only been carried out in a sectoral or regional areas of economy, for example; Salimifar (2005) utilized translog production function for computing total factor production growth in Khorasan province industry of Iran. The scholar applied Kendrik index for accounting total factor production level.

Askari et al. (2007) utilized the primer index, Solow index, Kendrik index, Divisia index and Tornvist index to investigate productivity in rural industries of Iran. The intellectuals compared all the production function (Cob-Douglass, Debertin, Translog and CES) and found that the Cob-Douglass production function was suitable for the industry. Bakhshali and Mojtahed (2005) carried out a comparative investigation of technology change on productivity of inputs in the industrial and agricultural sectors. The scholars utilized Cobb-Douglas production function to obtain technology change on productivity and found that the effects of technology change in industrial sector was more than the agricultural sector, technology change for industry and agricultural were 0.04 and 0.03 respectively.

However, given the volume of works done in other countries on the concept of productivity, much work still needs to be done within the Iranian context. So far these studies have only been applied to investigate productivity in total industries. On the other hand, lack of research related to productivity in food industry of Iran has existed as a problem for many years. To fill the existing gap discovered within the Iranian context, the current study will examine productivity in food industry of Iran.

\section{Methodology}

The objective of this paper is identifying place of food industries in term of productivity compared to total industry, Therefore, at first index method will be applied to measure total productivity levels and then will utilize econometrics method for estimation of TFP growth.

As said, production function expresses output as a function of the stock capital, employment, and a shift factor ( $t$ ), time, where the latter proxies the effects of productivity and technical progress. The subscript $t$ also represents time.

$$
Q_{t}=F\left(K_{t}, L_{t}, t\right)
$$

Assume that the argument " $\mathrm{t}$ " is separable from $\mathrm{K}$ and $\mathrm{L}$;

$$
Q_{t}=A_{t} F\left(K_{t}, L_{t}\right)
$$

This way, $A_{t}$ is referred to as exogenous, disembodied, and Hicks-neutral technical progress, and was measured by how output changes and time elapses with the input bundle held constant. Therefore, the notion of overall productivity can be reinterpreted as an index of all those factors other than labor and capital not explicitly accounted for but contributed to the generation of output.

$$
A_{t}=\frac{Q_{t}}{F\left(K_{t}, L_{t}\right)}
$$

\subsection{Kendrick Index}

Kendrick's index of total factor productivity for the case of value added as output, and two inputs can be written as:

$$
A_{t}=\frac{V_{t}}{F\left(r K_{t}, w L_{t}\right)}
$$


Where;

$A_{t}$ is the value of index in a given year,

$\mathrm{T}_{\mathrm{V}}$ is the added value; $w$ and $r$ denote the factor rewards of labor and capital respectively in the base year.

\subsection{Parametric Approach}

Parametric approach consists in econometric estimation of production functions to infer contributions of different factors and of an autonomous increase in production over time, independent of inputs. This later increase which is a shift over time in the production function, can be more properly identified as technological progress. It is one of the factors underlying productivity growth. Below commonly used specifications of production functions are given.

Cobb-Douglas Specification:

$$
Q=A_{0} e^{\lambda t} K^{\alpha} L^{\beta}
$$

Where, Q, L, K and $\mathbf{t}$ refer to output, labor, capital and time. $\alpha$ and $\beta$ give factor shares respectively for labor and capital. $\mathrm{A}_{0}$ describes initial conditions. Technological change takes place at a constant rate $\lambda$. It is assumed to be disembodied and Hicks-neutral, so that when there is a shift in the production function, K/L ratio remains unchanged at constant prices. Log-linear form this function can be written as:

$$
\ln Q=\ln A_{0}+\lambda t+\alpha \ln K+\beta \ln L
$$

\section{Data sources}

Annual data on output, value added, capital and labor for the food industries and total industries in two-digit were compiled for the period 1971-2006 from the Annual Survey of Manufacturing Industries published by the Statistical Centre of Iran. The variables were deflated by using price index of each group on the base year 1997 that published by Central Bank of Iran.

\section{Empirical results}

The levels of productivity between food industries and total industries are obtained by using Kendrick Index as exhibited on the equations below:

$$
\begin{aligned}
T F P_{t}^{\text {food }} & =\frac{V_{t}^{\text {food }}}{I N P U T_{t}^{\text {food }}} \\
T F P_{t}^{\text {tootal }} & =\frac{V_{t}^{\text {tootal }}}{I N P U T_{t}^{\text {tootal }}}
\end{aligned}
$$

Where, $Q_{t}^{\text {food }}$ is added value of food industries and $Q_{t}^{\text {total }}$ is added value of total industries in term of fix price (1997). INPUT food and INPUT total are value all used input in the food industry. The levels of productivity between food industries and total industries are summarized in Table (1). Also trend of total productivity and labor productivity illustrated in figures (1\&2).

The results of this study indicate that total factor productivity in food industries has been much lower than total industries (see figure 1), while labor productivity in food and total industries has been very close together, except that in recent years, total industries have been higher food industries (see figure 2).

To estimate of technological changes although panel data existed for food industries but due to lack of panel data for total industries, we have to use time series data for our estimations.

The Cob-Douglass production function form is applied for food industries as:

$$
\ln Q_{t}^{\text {food }}=\alpha_{0}+\alpha_{1} \ln K_{t}^{\text {food }}+\alpha_{2} \ln L_{t}^{\text {food }}+\gamma^{\text {food }} t
$$

And for total industries as:

$$
\ln Q_{t}^{\text {total }}=\alpha_{0}+\alpha_{1} \ln K_{t}^{\text {total }}+\alpha_{2} \ln L_{t}^{\text {total }}+\gamma^{\text {total }} t
$$

Where, $Q_{t}^{\text {food }}$ is output of food industries and $Q_{t}^{\text {total }}$ is output of total industries in the period 1971-2006.

The estimation of value of $\lambda^{\text {food }}$ and $\lambda^{\text {total }}$ are 0.09 percent and 0.16 percent for food and total industries respectively;

$$
\text { Ln } \mathrm{Q}^{\text {food }}=-186+0.52 \mathrm{~K}^{\text {food }}+0.91 \mathrm{~L}^{\text {food }}+\underline{\mathbf{0 . 0 9 t}}
$$

R-squared=0.99 t: (5.2) (3.5) (3)

$\operatorname{Ln} \mathrm{Q}^{\text {total }}=-333+0.24 \mathrm{~K}^{\text {total }}+1.2 \mathrm{~L}^{\text {total }}+\underline{\mathbf{0 . 1 6 t}}$ 


\section{R-squared $=0.99$ (1.8) (3.3) (4)}

The results of the estimation show that Technological changes in food industries have been lower than total industries over the 1971-2006 periods.

In general all results show that the productivity and Technological changes in food industries of Iran are not satisfactory and acceptable. This study was aimed to find out the reasons for this egregious difference between food and total industry of Iran in terms of labor productivity, total productivity and Technological changes.

Several reasons have been found for this problem; one of the findings was that the capital per worker in food industry was lower than the total industry in 1995-2005 periods (see Table and Figure 3). The capital per worker has a positive relationship with labor and total productivity. The low capital per worker causes a decrease in productivity. Another reason for having low productivity in food industry was that the ratio of women workers to men workers in food industry was higher than total industry (See Table 3 and Figure 4). According to empirical evidences female employees' productivity is generally less than male employees' productivity (Verner, 2000), (Crepon, Deniau, \& Perez-Duarte, 2002), (Kawaguchi, 2003) and (Liqin \& Xiao, 2006).

Finally, the differences between the educated workers in food industry and total industry can be one of the reasons for differential productivity in food and total industry (see Table 3 and Figure 5). Table 3 and Figure 4 show that the educated workers in food industries are less than in total industries in the overall period of 1995-2006. According to human capital theory, a higher education yields a higher productivity (Schultz, 1960). Empirical evidences related to human capital have proven this theory (Ballot, Fakhfakh, \& Taymaz, 2001), (Stephan \& Szalai, 2003), (Takii, 2003), (Lorraine, Reed, \& Reenen, 2006) and (Biesebroeck, 2007).

\section{Conclusion}

In conclusion, the importance of food industries, i.e. Priority of the Non-oil Exports in Foreign Trade, Respond to Nutrition of Population and Prevention of Wastage, and lack of research related to productivity in food industry of Iran have led to this study on the productivity in food industry of Iran over the 1971-2006 periods. The examination of the levels of labor productivity, total productivity and technical changes in food industries and compared with the total industries of Iran showed that labor productivity and total factor productivity in food industries were lower than the average total industries over the period. Also the estimation of technical changes show that the measurement of technical change in food industries was 0.09 percent while for total industries was 0.16 percent over the period. There have been several reasons for this egregious difference between the food and total industry of Iran in terms of labor productivity, total productivity and Technological changes. The reasons were due to lower capital per worker, lower educated workers and higher women workers in food industry in respect to total industry.

\section{References}

Bakhshali, S. \& Mojtahed, A. (2005). Comparative investigation of technology change on productivity of inputs in industry and agriculture sectors pajoheshhay eghtsadi, 32, 11-19.

Ballot, G., Fakhfakh, F. \& Taymaz, E. (2001). Firms' human capital, R\&D and performance: a study on French and Swedish firms. Labour Economics, 8(4), 443-462.

Biesebroeck, J. V. (2007). Wage and productivity premiums in sub-saharan africa. National Bureau of Economic Research, Working Paper 13306.

Carlsson, B. (1981). The content of productivity growth in Swedish manufacturing. Research Policy, 10(4), 336-355. Contini, B., Revelli, R. \& Cuneo, S. (1992). Productivity and imperfect competition: Econometric estimation from panel-data of Italian firms. Journal of Economic Behavior \& Organization, 18(2), 229-248.

Crepon, B., Deniau , N. \& perez-Duarte, S. (2002). wages, productivity, and worker characteristics:A French Perspective. France:Mimeo. Pariso.

Daly, M., Gorman, I., Lenjosek, G., MacNevin, A. \& Phiriyapreunt, W. (1993). The impact of regional investment incentives on employment and productivity: Some Canadian evidence. Regional Science and Urban Economics, 23(4), 559-575.

Eslava, M., Haltiwanger, J., Kugler, A. \& Kugler, M. (2004). The effects of structural reforms on productivity and profitability enhancing reallocation: evidence from Colombia. Journal of Development Economics, 75(2), 333-371.

Kawaguchi, D. (2003). Male-Female Wage and Productivity Diferentials: A Structural Approach Using Japanese Firm-Level Panel Data. Econometric Society Australasian Meetings, 303.

Kendrick, J. W. (1984). Improving company productivity. Baltimore: Johns Hopkins University Press.

Lach, S. (1995). Patents and productivity growth at the industry level: A first look. Economics Letters, 49(1), 101-108. Lam, P.-L. \& Lam, T. (2005). Total factor productivity measures for Hong Kong telephone. Telecommunications Policy, 29(1), 53-68.

Liqin, Z. \& Xiao, y. D. (2006). Male-Female Wage Discrimination in Chinese Industry: Investigation Using Firm-Level Data. GEM-IWG Working Paper 06-11. 
Lorraine, D., Reed, H. \& Reenen, J. V. (2006). The Impact of Training on Productivity and Wages: Evidence from British Panel Data. Oxford Bulletin of Economics and Statistics, 68(4).

Maniadakis, N. \& Thanassoulis, E. (2004). A cost Malmquist productivity index. European Journal of Operational Research, 154(2), 396-409.

McGinn, P. (2002). 'The single most important company.' Newsweek, 139, p. 55.

Mollick, A. V. \& Cabral, R. (2009). Productivity effects on Mexican manufacturing employment. The North American Journal of Economics and Finance, 20(1), 66-81.

Mullen, J. K. \& Williams, M. (1990). Explaining total factor productivity differentials in urban manufacturing. Journal of Urban Economics, 28(1), 103-123.

OECD. (2001). Measuring productivity-measurement of aggregate and industry-level productivity growth.

Pritchard, R. D. (1992). . Organizational productivity. In Dunnette, M.D. \& Hough, L.M. (Eds.) Handbook of Industrial/Organizational Psychology, Vol. 3, (2nd ed.).

Radam, A. (2007). Efficiency and Productivity of The Malaysian Food Manufacturing Industry, 1983-2000. Universiti Putra Malaysia.

Rushdi, A. A. (2000). Total factor productivity measures for Telstra. Telecommunications Policy, 24(2), 143-154.

Salimifar, M. (2005). Inputs productivity and utilization of them in big industries of Khorasan Province. Faslnameh pajoheshhaye eghtesadye Iran, 24, 33-52.

Schultz, T. W. (1960). Capital formation by education. Journal of Political Economy 68, 571-582.

Solow, R. M. (1957). "Technical Change and the Aggregate Production Function,". Review of Economics and Statistics, 39(3), 312-320.

Stephan, J. \& Szalai, K. (2003). Firm-Specific Determinants of Productivity Gaps between East and West German Industrial Branches (Publication in: http://ideas.repec.org/p/wpa/wuwpdc/0403002.html

Takii, S. (2003). Do Education Earnings Differentials Reflect Productivity?: Evidence from Indonesian Manufacturing 1996. The European Institute of Japanese Studies, Stockholm School of Economics, Working Paper 169.

Tinbergen, J. Z. T. (1942). Theorie der Langfristigen Wirtschaftsentwicklung. . Weltwirtsschaftliches Archiv, 55(1), 511-549(translated as On the theory of trend movements. In: Klassen, L.H., Koych, L.M., and Witteveen H.J., eds. Jan Tinbergen Selected Papers. Amsterdam: North Holland; 1959: 1982-1221.

Verner, D. (2000). Wage and Productivity Gaps: Evidence from Ghana. The World Bank Africa Technical Families Human Development Policy Research Working Paper 2168.

Weber, W. L. \& Domazlicky, B. R. (1999). Total factor productivity growth in manufacturing: a regional approach using linear programming. Regional Science and Urban Economics, 29(1), 105-122.

Windle, R. J. \& Dresner, M. E. (1992). Partial productivity measures and total factor productivity in the air transport industry: Limitations and uses. Transportation Research Part A: Policy and Practice, 26(6), 435-445.

\section{Notes}

Note 1. Larouse Etvmological Dictionary, 1946-49 Edition.

Note 2. Asian Productivity Organization (APO). Organization for Economic Co-Operation and Development(OECD) 
Table 1. labor productivity and TFP in food and total industries (fixed price)

\begin{tabular}{|c|c|c|c|c|}
\hline \multirow[t]{2}{*}{ Year } & \multicolumn{2}{|l|}{ Labor productivity } & \multicolumn{2}{|l|}{ Total productivity } \\
\hline & Food Industry & Total Industry & Food Industry & Total Industry \\
\hline 1971 & 0.419074 & 0.418037 & 0.143398 & 0.829021 \\
\hline 1972 & 0.547322 & 0.386809 & 0.136641 & 0.543355 \\
\hline 1973 & 0.592461 & 0.389315 & 0.160119 & 0.595152 \\
\hline 1974 & 0.452931 & 0.377472 & 0.100047 & 0.53501 \\
\hline 1975 & 0.451063 & 0.407327 & 0.104893 & 0.548073 \\
\hline 1976 & 0.596606 & 0.481387 & 0.135962 & 0.65074 \\
\hline 1979 & 0.360781 & 0.363538 & 0.118259 & 0.758586 \\
\hline 1980 & 0.353418 & 0.393839 & 0.154295 & 1.053975 \\
\hline 1981 & 0.405762 & 0.43764 & 0.153766 & 1.071234 \\
\hline 1982 & 0.363855 & 0.343862 & 0.14741 & 0.883038 \\
\hline 1983 & 0.341752 & 0.359971 & 0.130723 & 0.88424 \\
\hline 1984 & 0.307335 & 0.355228 & 0.115829 & 0.901605 \\
\hline 1985 & 0.337856 & 0.333989 & 0.138331 & 0.930905 \\
\hline 1986 & 0.271882 & 0.260908 & 0.091822 & 0.554662 \\
\hline 1987 & 0.212396 & 0.231035 & 0.091146 & 0.628634 \\
\hline 1988 & 0.307694 & 0.260323 & 0.098914 & 0.579632 \\
\hline 1989 & 0.250194 & 0.244317 & 0.095668 & 0.630191 \\
\hline 1990 & 0.61794 & 0.590208 & 0.153284 & 1.023927 \\
\hline 1991 & 0.386334 & 0.372798 & 0.128583 & 0.884586 \\
\hline 1992 & 0.338733 & 0.366721 & 0.102741 & 0.795847 \\
\hline 1993 & 0.43567 & 0.387642 & 0.126332 & 0.772406 \\
\hline 1994 & 0.430933 & 0.400857 & 0.105558 & 0.727541 \\
\hline 1995 & 0.326485 & 0.334088 & 0.095639 & 0.659666 \\
\hline 1996 & 0.315638 & 0.370592 & 0.091565 & 0.719743 \\
\hline 1997 & 0.352647 & 0.428602 & 0.090005 & 0.758803 \\
\hline 1998 & 0.368705 & 0.414514 & 0.095418 & 0.730456 \\
\hline 1999 & 0.379319 & 0.455628 & 0.09742 & 0.774861 \\
\hline 2000 & 0.353902 & 0.49906 & 0.078792 & 0.737476 \\
\hline 2001 & 0.350024 & 0.543125 & 0.071333 & 0.7382 \\
\hline 2002 & 0.405686 & 0.546085 & 0.07258 & 0.678622 \\
\hline 2003 & 0.389732 & 0.622189 & 0.058277 & 0.625237 \\
\hline 2004 & 0.378778 & 0.695975 & 0.048675 & 0.593204 \\
\hline 2005 & 0.440355 & 0.740551 & 0.055071 & 0.593145 \\
\hline 2006 & 0.466378 & 0.891648 & 0.050571 & 0.60538 \\
\hline
\end{tabular}

Table 2. the estimated coefficients model( $(9$ and 10$)$

\begin{tabular}{|l|l|l|l|l|}
\hline TYPE & \multicolumn{2}{|c|}{ Total Industries } & \multicolumn{2}{c|}{ Food Industries } \\
\hline Variables & Coefficient & Prob & Coefficient & Prob \\
\hline YEAR & 0.165844 & 0.0004 & 0.091940 & 0.0068 \\
\hline LNCAPITAL & 0.244035 & 0.0807 & 0.522019 & 0.0000 \\
\hline LNLABOR & 1.213964 & 0.0022 & 0.914750 & 0.0015 \\
\hline C & -333.8040 & 0.0003 & -185.9852 & 0.0047 \\
\hline R-squared & 0.994893 & F-statistic $=1363.675$ & 0.997627 & F-statistic $=2942.976$ \\
\hline
\end{tabular}


Table 3. Comparison the effective factors on productivity in food and total industries of Iran

\begin{tabular}{|c|c|c|c|c|c|c|}
\hline \multirow{2}{*}{$\begin{array}{l}\text { FACTORS } \\
\text { YEAR } \\
\end{array}$} & \multicolumn{2}{|c|}{ WOMEN/MEN WORKERS } & \multicolumn{2}{|c|}{ EDUCATED/TOTAL WORKERS } & \multicolumn{2}{|c|}{ CAPITAL/WORKER } \\
\hline & TOTAL & FOOD & TOTAL & FOOD & TOTAL & FOOD \\
\hline 1995 & 0.071814 & 0.092859 & 0.265471 & 0.214457 & 96.54142 & 92.64408 \\
\hline 1996 & 0.070085 & 0.09036 & 0.277107 & 0.226396 & 84.77112 & 78.5319 \\
\hline 1997 & 0.070125 & 0.087929 & 0.292787 & 0.235041 & 80.19843 & 74.37536 \\
\hline 1998 & 0.068223 & 0.091879 & 0.31661 & 0.252782 & 76.33469 & 69.67883 \\
\hline 1999 & 0.071078 & 0.103979 & 0.343219 & 0.280705 & 69.67883 & 61.47476 \\
\hline 2000 & 0.072707 & 0.101422 & 0.373005 & 0.311306 & 54.23188 & 48.35162 \\
\hline 2001 & 0.079981 & 0.113459 & 0.407039 & 0.33113 & 49.52076 & 44.94791 \\
\hline 2002 & 0.078599 & 0.108372 & 0.438666 & 0.376091 & 44.81377 & 41.0496 \\
\hline 2003 & 0.089058 & 0.127317 & 0.475007 & 0.403963 & 42.63445 & 36.46586 \\
\hline 2004 & 0.096438 & 0.139236 & 0.506575 & 0.440129 & 44.85096 & 39.20174 \\
\hline 2005 & 0.098199 & 0.144939 & 0.531632 & 0.470181 & 46.96252 & 38.7642 \\
\hline 2006 & 0.103634 & 0.152379 & 0.578338 & 0.503228 & 55.34027 & 42.47298 \\
\hline
\end{tabular}

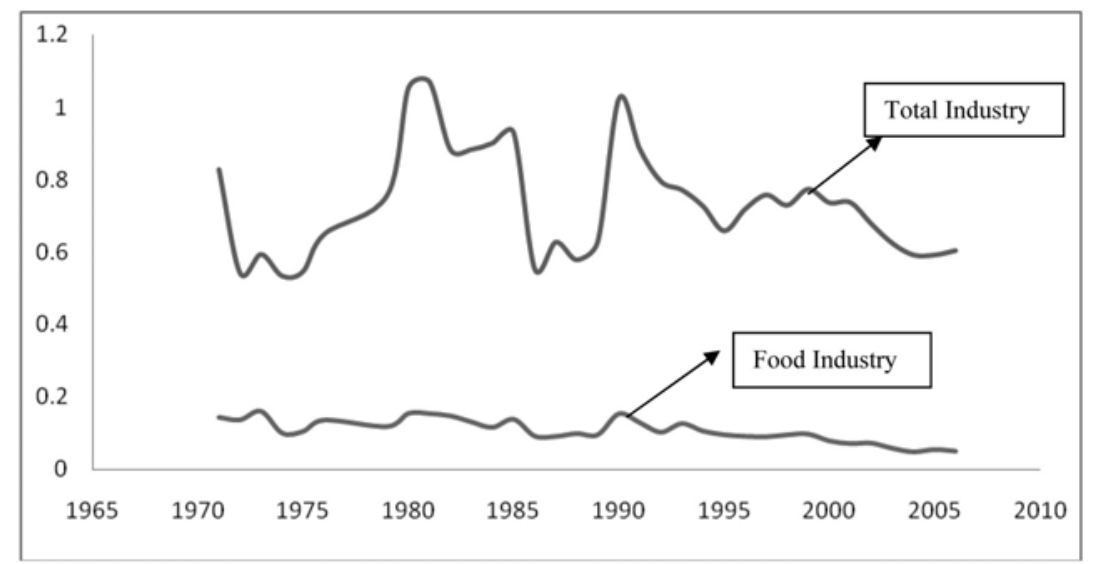

Figure 1. Total factor productivity in food industries and total industries

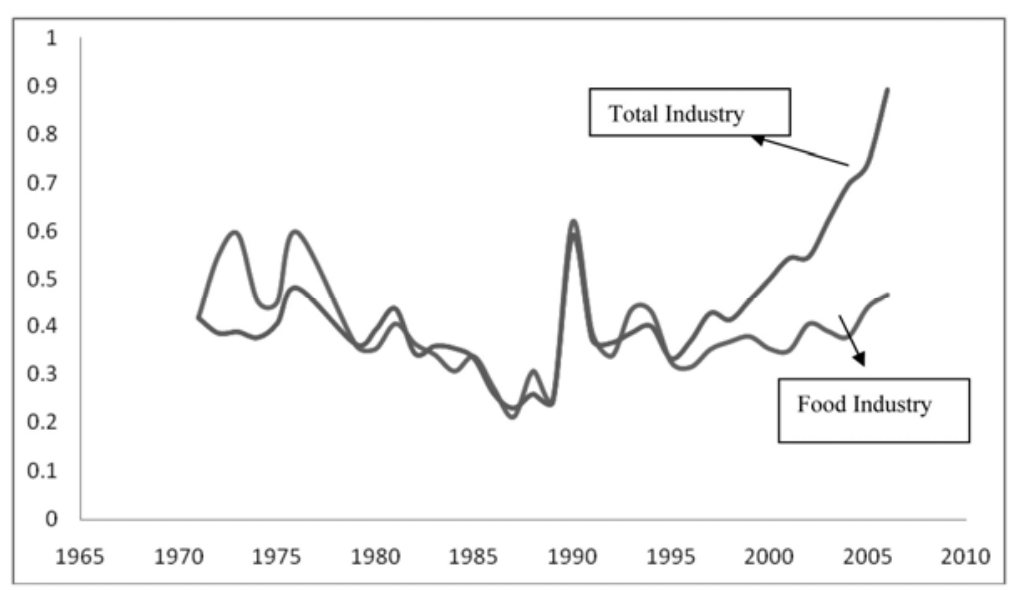

Figure 2. Labour productivity in food industries and total industries 


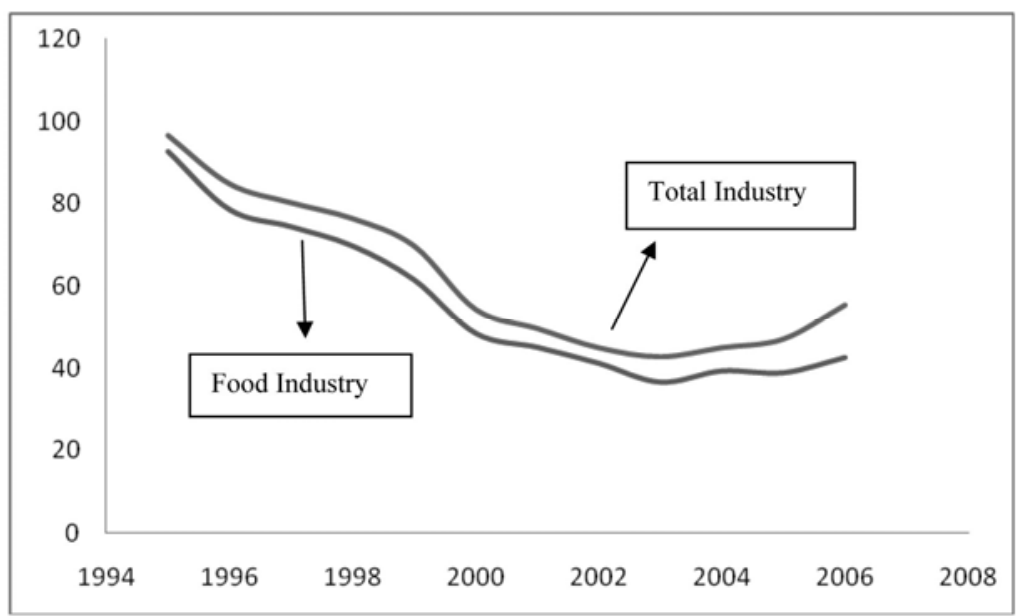

Figure 3. Capital per worker in food and total industries of Iran

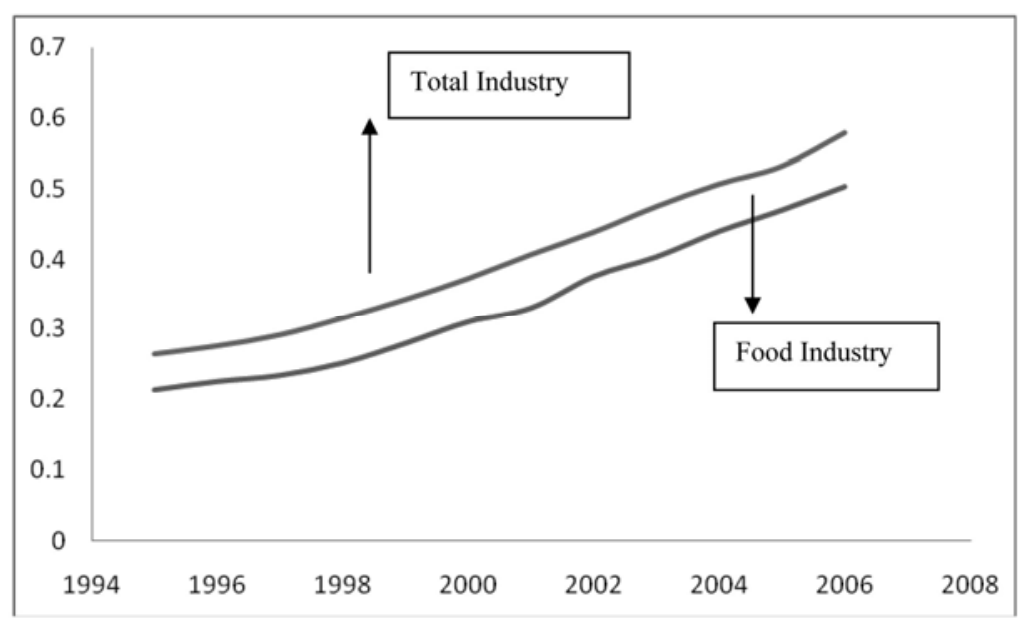

Figure 4.The ratio of educated workers to total workers

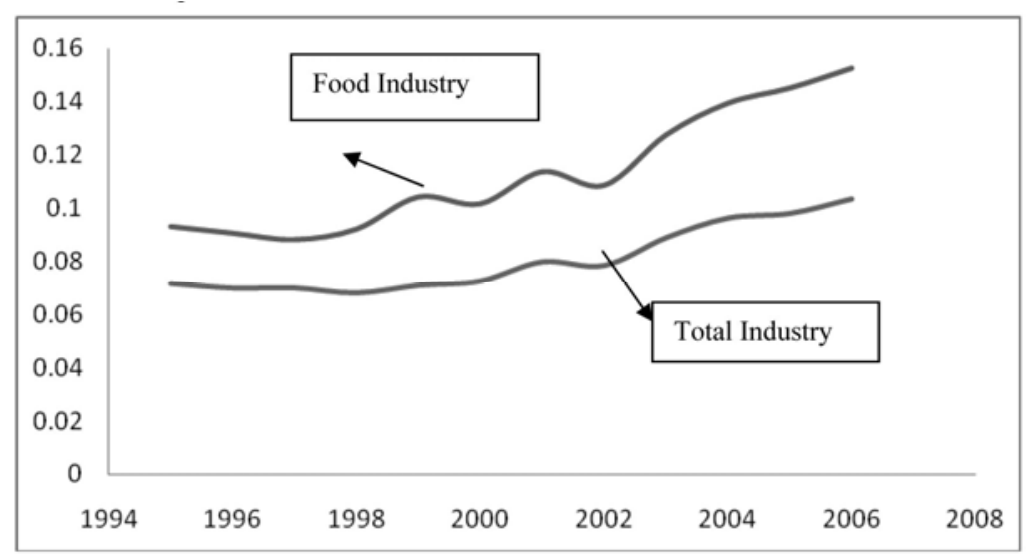

Figure 5.The ratio of women workers to men workers 